\title{
A BIBLICAL, CULTURAL AND MISSIOLOGICAL CRITIQUE OF TRADITIONAL CIRCUMCISION AMONG XHOSA-SPEAKING CHRISTIANS ${ }^{1}$
}

\author{
J. Papu ${ }^{2}$ and P. Verster ${ }^{3}$
}

\begin{abstract}
Among the Xhosa of South Africa, male circumcision remains a very important ritual. The question as to whether Christians should accept these rites and continue to send their children to traditional schools practising it is very important. In this article the implications of the ritual and the way in which proponents use the Bible are evaluated. It is argued that there should be an honest encounter with the rite from a biblical perspective. Solutions should be evaluated and explained. From a Christian perspective total rejection is not possible, but the church should remain faithful to the truth of the gospel.
\end{abstract}

\section{INTRODUCTION}

It has been argued convincingly by Bediako (1995:213) that Africans do not have to go too far before they find familiar terrain in the gospel. However, a "vigorous development of autochthonous African Theology", as argued by Bosch (1991:452), becomes impossible if the gospel is not allowed to evaluate the tradition and seek ways of either transforming it and/or discarding certain elements in it that are not congruent with its tenets (Edward Rommen quoted in Hesselgrave 1991:109, 110). Circumcision is one such difficult aspect of African life.

Circumcision is accepted as a principal form of initiation by the Xhosa-speaking people (Magubane 1998:33). In spite of the increasing reports of initiates who suffer medical complications, and even death, this traditional practice does not show any signs of abating. The Xhosaspeaking people still practise the ritual in its attenuated form and every aspect and phase in it is rich in meaning (Magubane 1998:33).

1 This article is based on the M.A. Dissertation of J. Papu. It was written from the perspective of Adventists, but the conclusions are relevant for all Christian communities.

2 Rev. J. Papu, postgraduate student, Department of Missiology, University of the Free State, and Pastor of the Seventh-day Adventist Church.

3 Prof. Pieter Verster, Head of the Department of Missiology, University of the Free State, Bloemfontein. 


\section{METHODOLOGY AND RESEARCH PROBLEM}

The basic method assumed in this study is a comparative literary method, including exegesis and theological reflection. In this article the question to be asked is whether circumcision as practised among the Xhosa can be accepted in the Christian community, or whether the Christian community should rule against any form of continuation of this traditional rite. The research will furthermore look at biblical views on circumcision as it occurred in biblical times and establish the correct evaluation of these aspects. Finally a suggestion for the church's way forward in dealing with it is made.

\section{THE PROCEDURE AND PURPOSE OF CIRCUMCISION}

\subsection{The procedure/ritual of circumcision}

Although there were times when circumcision was not practised in the whole community, and, in the case of Pondoland, when it was outlawed by chief Faku (who died in 1867) (Hunter 1936:165), it is a generally accepted practice among the Xhosa. The event is usually conducted for those who are between the ages of 15 to 25 years (Meintjies 1998:7). Circumcision for those younger than this age is not encouraged by Xhosaspeaking communities.

La Fontaine (1985:25) observes a tripartite form in all rituals of transition, namely separation, a liminal phase and integration. Circumcision as a form of a ritual of transition clearly follows three distinct stages: these are surgical operation, seclusion and a coming out ceremony or reincorporation into the community (Ngxamngxa 1971:186). It is in this light that the following statement is made:

Among the Xhosa-speaking tribes if a man is to consider himself as a man he must have gone through these stages (Ngxamngxa 1971:186).

It is the combination of these three stages that completes the rite of circumcision. There may still be variations in so far as how these stages are observed (Gitywa 1976:178-179). 


\subsubsection{First stage: surgical operation}

The actual operation is usually preceded by ritual preparations (Ngxamngxa 1971:186). Already by this time the building or the lodge of the initiates (ithonto), together with the appointment of ikhakbanta (traditional attendants) during the seclusion, has taken place (Soga 1931:249). Part of ritual preparations, in some Xhosa-speaking groups, includes the killing of a sacrificial beast (umngcamo). Initiates are expected to eat a certain part of the beast, usually a strip of meat cut from the right leg (Ngxamngxa 1971:187). The next ritual act is usually the shaving of the boy's head (Ngxamngxa 1971).

The ritual core of initiation is circumcision, meaning the actual surgical operation, and it is an irreversible symbol of the social maturity of the individual (Gitywa 1976:180). It is this act that remains as a permanent sign that one has been circumcised. The operation, which is the severing of the foreskin, is done by the ingcibi (traditional surgeon). It is done outside of the lodge and the initiates are immediately led to the lodge after the operation (Gitywa 1976:181). The initiates have to repeat after the surgeon as he says, "You are the man" (Unpublished document). After severing, the skin is handed over to the owner and it is usually buried later in an ant-heap where it will be devoured by the ants (Gitywa 1976). The wound is then covered with herbs and the initiates move into the lodge (Ngxamngxa 1971:188).

\subsubsection{Second stage: seclusion}

The period of seclusion begins immediately after the operation. Soga (1931:257) observes that there is no regular time limit for the period of seclusion. This period can last from one month to twelve months. However, nowadays this period usually coincides with the long school breaks either in winter or summer, to allow the initiates to return to school.

The first eight days are regarded as the most critical and most painful for the initiates. During the first eight days of seclusion the initiates are debarred from fresh food, green food, meat and water (Soga 1931:254). This eight-day period culminates in an illustrious event called ukosiswa, the main objective of which is to release the initiates from certain food and other taboos (Ngxamngxa 1971:189). An animal is killed on this day and the initiates are allowed to eat its meat. 
The initiates are still expected to observe certain taboos even after this ceremony. They wear a peculiar dress during this time (Ngxamngxa 1971:189). The initiates pass the time by engaging in various traditional games, hunting, dancing, etc. (Ngxamngxa 189).

\subsubsection{Third stage: coming out ceremony}

The end of the seclusion is marked by ceremonies releasing the boy from the marginal status of previous months (Van der Vliet 1974:231). The termination of the seclusion and preparation for reincorporation into the community is usually begun by a race to the river, or a ritual washing where there is no river (Ngxamngxa 1971:190). After the washing butter or red ochre is applied by an appointed person. After this, the initiates are led to the kraal of the usosuthu (usually at the house of one of the fathers of the initiates). This happens after the hut or the lodge has been burnt and, under strict instruction, the initiates are not to look back at the burning lodge (Gitywa 1976:189).

It is while they are in the kraal that the ceremony of ukuyala begins. Here they are harangued and admonished by the older men about their new status (Gitywa 1976:189).

The theme of the speech is the same, mention being made of the new status attained by the novices and the responsible and dignified conduct expected of them (Gitywa 1976:190).

This ceremony is also characterised by ukusoka which consists of the giving of various gifts to the amakrwala (newly initiated) (Ngxamngxa 1971:191).

\subsection{Function and meaning of circumcision}

Circumcision is prominently and distinctly expected to "transform the irresponsible and intractable boy into a man with an adult dignity and self-respect" (P. Mayer, quoted in Gitywa 1976:203). President Nelson Mandela, himself a Xhosa, wrote the following, in his autobiography: "I count my days as a man from the date of my circumcision." (Quoted in Robert Block, Sunday Times [London], p. 18, 29 December 1996).

In spite of the current spate of deaths reported in initiation schools, many young Xhosa-speaking boys still flock to these schools at the risk of dying or being maimed during the process. Circumcision therefore 
continues to occupy a central point in the socio-cultural life of the Xhosaspeaking people.

While circumcision can be regarded as a rite of transition from boyhood to manhood as observed above, it can also be regarded as one of the agents of transition. This observation is succinctly argued by Driver (1991:93) when he says, "Rites of passage are performed not simply to mark transitions but to effect them." In cases in which the expected outcome is not realised after the ritual, the blame is put on the initiate for his lack of mental capacity or in some cases on the way the ritual was performed with some aspects of it not being properly observed (Young 1965:74). In general those who undergo the ritual do show distinct signs of change in behaviour and lifestyle.

The following are the aspects that circumcision, as a form of initiation, marks and effects in the life of the Xhosa speaking people:

\subsubsection{Sociological significance}

Gitywa (1976:203) observes that one of the most important things in the life of a newly initiated (ikrwala) is a change of behaviour. A clear distinction can be seen between a boy who is not circumcised and the man who has. Anti-social behaviour is characteristic of boys and not men (Gitywa 1976). A boy is not regarded as a complete person (Document: 1987 January).

The horizontal relationships that are altered include the one between the initiate and his mother and women in general. It also includes his new status with other men as well. The right to procreate and establish a family of his own is also part of this new change.

However, the most important aspect is the vertical relationship that involves ancestors (Gitywa 1976:204). The initiate is taught to honour and respect the ancestors by adhering to the customs and carrying forward the rituals that he witnessed, to his progeny (Gitywa 1976:207).

\subsubsection{Psychological significance}

There is a pronounced and expected change of personality in the initiate. At the coming-out ceremony, the initiates are anointed by a chosen person who is known to be of good repute in the hope that his charisma and good qualities will rub off on the youth (Gitywa 1976: 
208). This is further emphasised during the service of ukuyala (admonition) in which the initiates are reminded of their newly acquired status, and the wearing of new clothes signifies a change of character (Ngxamngxa 1971:201).

Ngxamngxa (1971:201), Gitywa (1976:208-209) and Mbiti (1969: 121) all agree that circumcision symbolises death and rebirth. Mbiti argues that the "ritual seclusion is a symbolic experience of the process of dying" (quoted in Gitwya 1976:209), while Ngxamngxa (1971: 201) notes that painting the young candidates represents the "venix caseosa" with which an infant is born.

Van der Vliet (1974:230) observes that, in some cultures, when a boy dies during the circumcision period, he is buried secretly and the parents are only informed at the end of the ritual. She also adds the following:

The dead initiate is often not publicly mourned, suggesting that the boy they had known was "dead" anyway and the man had not yet been born.

The age of the initiate is usually reckoned from the year of circumcision (Gitywa 1976:208).

\subsubsection{Educational significance}

The beating and the physical ordeal and pain that accompany the ritual of circumcision is designed to effect discipline and to prepare the youth for the hardships of manhood (Van der Vliet 1974:230). La Fontaine (1985:25) observes that pain and physical ordeal are common in rituals of maturity. Formal teaching is also reported in that the initiates are told and taught how to behave as men (Ngxamngxa 1971: 195). New vocabulary is acquired that seeks to create a bond of solidarity between the initiates and an attitude of respect.

\subsubsection{Religious and magical significance}

Soga (1931:248) argues that,

[W]hile there is no religious ceremony connected with the rite of circumcision, that it has a religious significance is not doubted. 
When the initiate has completed the rite of circumcision he is expected to enter into a new relationship with the ancestors (Soga 1931). The killing of animals during initiation is said to involve dedicating the victims to the ancestors (Ngxamngxa 1971:192). The meat eaten during $u$ kosiswa is believed to bolster courage and give protection against evil influence (Soga 1931:254). The man who is appointed to anoint the initiates is chosen so as to pass his good virtues and charisma to them (Ngxamngxa 1971:192ff.).

As can be seen, the ritual of circumcision is fraught with meaning for the traditional Xhosa-speaking people. Some have also argued that it is because of the strict observation of such rituals that the Xhosa as a people have been sustained and kept from extinction.

\section{BIBLICAL JUSTIFICATION FOR THE RITUAL OF CIRCUMCISION}

The Biblical texts used during ukuyala reflect the theological understanding of the significance of the ritual among some Xhosa-speaking Christians. As observed earlier, the Bible is used to justify the ritual in at least three ways: The first is the argument of origin (Genesis 17:1014, 23-27). The second argument is that of missiological significance (Acts 16:3), and the third is the moral argument (Deuteronomy 10:16; Philippians 3:3).

\subsection{Argument of origin}

The basic argument here is that the ritual of circumcision dates as far back as the Old Testament. However, the events leading to the Jerusalem Council, as recorded in Acts 15, leave us in no doubt that the role of circumcision had begun to take on a strictly cultural significance. The conversion of Cornelius recorded in Acts 10 proved beyond reasonable doubt that God had accepted the Gentiles without the ritual of circumcision. James Dunn (1996:146), commenting on why the Holy Spirit preceded baptism in the case of Cornelius, says:

God had to give so clear an indication of his will otherwise even Peter might have hesitated to take such a bold step in the case of Gentiles without first requiring them to be circumcised. 
This shows that up to that point, even in the minds of the early church leaders, circumcision was binding even for Gentiles. According to Scott Spencer (1997:116), "[T]he outpouring of the Holy Spirit creates remarkable social unity". The two groups, one circumcised and the other uncircumcised, are now bound together in the community of God's people. This happens without any requirement for the Gentiles to be circumcised, for the Holy Spirit "has broken through such barriers in forceful, undeniable fashion..." (Spencer 1997:117).

The resolution recorded in 15:19 emphasises the importance of "turning to God". On this Dunn (1996:204) argues:

The critical factor in the acceptability of Gentiles to the believing Jews should be the fact of their conversion to God and thus acceptance to God.

The interesting point highlighted by Spencer (1997:156-157) is that here James uses the same verb (parenochlein) which was used by the Jews in the Maccabean revolt signifying the Jews' resolution to observe their laws. The point is that the Gentiles should not be put into a similar position (parenochlein) by pressurising them into keeping the Jewish laws.

It should be remembered, at this point, that the initial question that was raised in Antioch implied that Gentiles had to be circumcised if they wanted to be saved (Acts 15:1). The stipulation reflected in 15:20 should not be seen as a modified list of things that Gentiles should do in order to be saved. However, according to Justo Gonzalez (2001:176), the question was not about how much of the law should be obeyed in order to be a Christian. It was rather: How much of the law should one obey in order to live in the midst of Israel?

It would be unbiblical to ignore this resolution and to seek to derive meaning by appealing to the Old Testament in an attempt to justify the continued observance of circumcision. This resolution limits and restricts the ritual of circumcision to the Jews only.

Immediately after the Jerusalem Council, Paul is reported to have circumcised Timothy (Acts 16:3). The concern is whether this can be used to justify a continued observance of circumcision by non-Jewish Christians or not. Was Timothy circumcised in order to advance the mission of the church? How can this act be reconciled with the Jeru- 
salem Council? This brings us to the next argument used to defend the practice of circumcision.

\subsection{Missiological argument}

Paul's teaching on circumcision is clearly reflected in several texts in the New Testament. In Romans 2:25-29, he seems to be pointing out that it is obedience to the law of God that counts and not mere circumcision. He also advocates a spiritual circumcision, that of the heart. We see the same trend in 1 Corinthians 7:17-24. His instruction to all churches $(7: 17)$ is that men should remain what they are when they become Christians. He argues that "circumcision and uncircumcision are both nothing" (7:19). The same line of reasoning and argument can be seen in Galatians 6:15. For Paul, what counted more was a new creation, and neither circumcision nor uncircumcision counted for anything.

While conceding that Timothy's circumcision was a matter of missionary strategy at the very least, Polhill (1992:343) succinctly argues for a matrilineal principle: that Timothy, due to his mother being a Jew, would then qualify as a Jew in the eyes of the Jews. As a Jew his circumcision would then be required, in keeping with the Jerusalem resolution and consistent with Paul's teaching on circumcision in the epistles.

Does the circumcision of Timothy really provide a legitimate basis for the Xhosa-speaking Christians to practise circumcision? If so, the apparent refusal by Paul to circumcise Titus (Galatians 2:3) would clearly challenge this argument. To simply assert that Paul's circumcision of Timothy justifies the practice of circumcision by the Xhosaspeaking Christians is a gross oversimplification of Paul's view on circumcision.

Raymond Brown (1997:306) makes a striking observation when he asserts that there are two accounts of the Jerusalem Council; one is found in Acts 15 and the other in Galatians 2. The account as given by Luke in Acts 15 gives a simplified and less acrimonious report of what took place in this Council. However, as regards Paul in Galatians, a personal account written in self-defence, which also reveals the acrimonious nature of the debates in the Council, is presented (Brown 1997:306). 
In the book of Galatians circumcision is first mentioned in chapter $2: 3$, with reference to Paul's refusal to circumcise Titus. The entire book seems to reflect a tacit assumption that circumcision was the main point of controversy between Paul and his opponents (Ridderbos1979:82). To have brought a Gentile convert by the name of Titus into the predominantly Jewish Council, argues Brown (1997:307), was "a shrewd manoeuvre" by Paul. It offered the audience a first hand, face to face opportunity to meet a Christian Gentile who was not circumcised. It is clear therefore that the circumcision of Timothy must be counterbalanced by Paul's refusal to circumcise Titus, as reflected in Galatians. Timothy was a Jew and Titus a Gentile, so Paul was in harmony with the Apostolic Council's resolution.

\subsection{Moral argument}

It is true that the Bible does make a clear distinction between circumcision of the heart and that of the flesh. Xhosa-speaking Christians have used this to show that the ritual of circumcision has as its goal a change of lifestyle. It would seem that even Christians tend to believe that without the circumcision of flesh, a moral change is not possible.

It is clear from the Bible that for the Jews, circumcision was both physical and ethical (Deut. 30:6, Gen. 17:10-14). According to Genesis (17:11), physical circumcision was a sign of the covenant between Israel and God. "By circumcision," writes Palmer Robertson (1993:54), "a testimony was given to the world, and a person was sealed in his membership with the organized community of the covenant". It should be noted that circumcision in the Biblical sense was not a sign of entrance into manhood as it is with Xhosa-speaking people; instead it was a formal sign of membership of the covenant community (Robertson 1993:55).

Wenham (1994:24) explains that circumcision had a specific relation to the covenant. The emphasis was on the ethical implications for humans:

This does not exclude the notion that circumcision may have reminded God of his promises, but it seems likely that its primary function was manward, to remind the Israelite man to walk blamelessly with God, as Noah and Abraham did. 
According to Thomas McComiskey (1985:37), this covenant community constituted

a people who by virtue of God's faithfulness to His promise owe to God the debt of obedience to His commands.

Those who become members of this covenant and do so by physical circumcision are

to maintain the purity of heart and deep sensitivity to the will of God as reflected in the concept of ethical circumcision (McComiskey 1985:37).

Dunn (1998:422) indicates convincingly that the Jews had always emphasised the necessity of a circumcised heart, the only difference being that they entertained the hope that this would be realised in future. $\mathrm{He}$ argues that for Paul the above claim and hope was realised among the early Gentile and Jewish believers, meaning that "their conversion could be described as an act of circumcising the heart by the Spirit". This hope, as he (Dunn 1998) concludes, "was fulfilled in the gift of the Spirit".

In the New Testament, circumcision as the sign of inclusion in the covenant community loses its strength and becomes of relative importance, if not just a cultural ritual. John Walton (1994:118) sees "baptism as an initiation sign just as circumcision was for the Abrahamic phase". While we observe an exemption for the Gentiles to observe circumcision, baptism seems to be requisite for both the Jews and the Gentiles (Acts 2:38). The covenant of grace has baptism as its sign, and this also incorporates women (Robertson 1993:57; Kline 1967:94).

However, as noted by Dunn (1998:454-455),

It is the gift of the Spirit, not baptism, which provides the new covenant answer to the old covenant circumcision.

What Dunn seeks to show here is that it was the presence of the Spirit in the life of the Gentiles that made the ritual of circumcision redundant and unnecessary. Dunn (1998:455) also sees the sociological significance of baptism as functioning in the same way as circumcision.

We have looked briefly at the threefold Biblical arguments given by Xhosa-speaking Christians in an attempt to justify the continued observance of circumcision. We have argued that Timothy was circumcised because he was seen as a Jew in the eyes of the Jews. His circum- 
cision was more expedient than prudent. We also argued that both in the Old and New Testaments, spiritual conversion was not dependent on physical circumcision. Baptism substituted circumcision and was required of both the Jews and Gentiles, unlike circumcision. There is therefore no Biblical justification and support for the arguments raised by Xhosa-speaking Christians for their continued observance of the ritual of circumcision.

\section{CONTEXTUALISATION AND CIRCUMCISION}

It is in this vein that Pauw (1975:66) observes that Western Christianity has persisted "relatively unchanged and unrelated to Xhosa tradition among the Xhosa-speaking believers." This shows that more aspects of Western Christianity still abound in many African Christians but for some reason these are not related to the African traditional life. Pauw (1975:66) argues that many Xhosa Christians tend to act in terms of certain Xhosa traditions in the homestead. On the surface this creates a "double life" for the Christians, a life in the church which is regulated by Western Christianity, and one in the homestead, which fits in with the African tradition. As a result of this "schizophrenic" condition, Xhosa-speaking Christians can practise the ritual of baptism in the church and that of circumcision at home with ease and with no sense of contradiction.

This superficial treatment of the culture is the reason for the lack of understanding of both the Biblical position and the traditional cultural significance of the ritual of circumcision by Xhosa-speaking Christians. Below is an attempt to explore the principles that should guide Xhosa-speaking Christians in their enculturation process and in dealing with circumcision.

\subsection{Challenge of inculturation}

Bosch (1991:447) succinctly argues that, "The Christian faith never existed except as translated into culture." However it is the dynamics of this process that have always created a problem for the church. This process appears to be a two-edged sword, as, on the one hand, it might lead to a transformation of culture, and, on the other, to a distortion of Christianity. This is observed by Bosch (1991:291) when he quotes 
Eugene Smith, and remarks that the relationship between culture and Christianity has been one of the major compromises of the Christian mission.

Christ is heralded as the pioneer in a radical way in this process of inculturation. Okure (1990:62) decisively asserts that the "incarnation of Christ constitutes an integral part, a necessary aspect of inculturation." For Christ this process consisted of "self-emptying" (Ephesians 2:6-11). This self-emptying was not only a display of Christ's love but, far more importantly, a willingness and intention to bridge the barrier between humanity and divinity (John 1:1-3, 12).

According to Okure (1990:57, 58), "incarnation presupposes a union of two realities, where each reality is enriched and mysteriously transformed by the other." It is clear, that in this process, Christ took his divinity seriously without denigrating the human element which he assumed after incarnation. It is in this sense that the author of Hebrews 2:14 emphasises the benefit accrued to Christ in the incarnation process.

\subsection{History of mission in Africa}

Much of the eighteenth century missionary activity suffered from a serious lack of appreciation of the difference between culture and the content of the gospel. The ground gained by the early church, as seen in Acts 15, of making the Gentiles Christians and not Jews, was lost sight of in subsequent years. The failure by the early missionaries in Africa to effect a proper and Biblical inculturation led to a distortion of Christianity and an unnecessary elimination of most African cultures.

A similar observation is made by Van der Walt (2003:26) when he asserts that the "conflict between Western individualism and African communalism is a conflict between two idolatries..." The following is an elaborated view of the same author when he notes:

[T]he Gospel provides a correcting, liberating invitation to both individualism and collectivism. The Gospel calls people in a communalistic society to an experience of the fullness of being human that communalism has denied them: the experience of individuality and a diversity of societal relationships. For those of us living in an individualistic society, the same Gospel calls us to an experience of the fullness of being human that individualism has denied: the experience of community (2003:157). 
This shows once more the inherent weakness of judging another culture on the basis of one's culturally determined predispositions (Hesselgrave 1991:123). It is the gospel and not another culture that should evaluate the proximity to or distance from the moral absolute in any culture.

\subsection{Creation of an indigenous church}

It can be readily conceded that the ideal purpose of inculturation should be the creation of an indigenous church. The goal of mission, argues Bosch (1991:450), has always been the establishment of an indigenous church. This goal has not always been met with true and Biblical success. A brilliant formula was devised to evaluate the authenticity of an indigenous church. This was formulated as the three "selfs" (Bosch 1991:450), given as self-government, self-support and self-propagation. However, as observed again by Bosch (1991:450), these churches could only exist when they learned to please their founders and by segregating themselves from the surrounding cultures. This produced replicas of Western churches in Africa. Bosch (1991:451) decisively and correctly indicates that it is only the introduction of the fourth "self" that will make a difference. By the fourth "self" he means "self-theologising". This is the only way in which there could be a development of an "autochthonous African theology" (1991:452). In this sense, for Bosch (1991:454), inculturation becomes the flowering of a seed implanted into the soil of a particular culture.

\section{RECOMMENDATIONS AND GUIDELINES FOR DEALING WITH THE ISSUE OF TRADITIONAL CIRCUMCISION}

\subsection{Areas of concern}

The following are areas in the ritual of circumcision that are posing problems for Christian theology and the church's understanding of the Bible.

These areas will be grouped under two headings: syncretism and Biblical conversion. While it can be argued that these two are not necessarily separate units, for the sake of clarity we shall consider them separately. 


\subsubsection{Syncretism}

While commendation is appropriate for some aspects that have been discarded in the way the ritual of circumcision is conducted by Christians, the very process seems to justify those aspects that have not been discarded. It was mentioned earlier that, for many Christians, except in a few areas, the person doing the surgical operation is the traditional surgeon. The acceptance of this person's credentials may actually imply approval of the institution that has qualified him. Christians in general do not subscribe to the traditional belief in the power of the inyangas (traditional healers). But for some reason they are willing to leave their children in the hands of traditional surgeons, simply because this is how it has always been done in the traditional context.

It is also very clear that the whole process is deeply entrenched in the traditional system of belief. It cannot be separated from the incantations and prayers offered at the initiation. Christian parents should ask themselves whether it is in order to leave such an important facet of education in the hands of traditional doctors.

It would be difficult to explain to a person going through ordeals during circumcision, the significance and the benefit of this experience in Biblical terms. It has been argued, as reflected above, that this is designed to effect discipline and to prepare the youth for the hardships of manhood (Van der Vliet 1974:230). Failure to speak against such hardships, in spite of their alleged pedagogical intentions, implicates the church in complications that have resulted from this practice.

\subsubsection{Biblical conversion}

One of the disheartening observations in the whole ritual of circumcision as practised by Xhosa-speaking Christians is the anticipation and expectation of a type of conversion experience for the boys. As Graeme Meintjies (1998) says in the title of his book, this is indeed "Manhood at a price."

People with good morals, who lead a virtuous life and are seen to be successful and respected, do have a positive influence and can serve as role models to the initiates. But this idea of influence is taken to extreme lengths when it is loaded with religious and magical expectations and some form of impartation of good qualities. The use of 
ministers in the ritual of anointing reveals the seriousness with which this is regarded by Xhosa-speaking Christians.

It can be concluded that Xhosa-speaking Christians have yet to produce a legitimate and cohesive inculturation of the ritual of circumcision. Members and families need guidance from the leadership of the church for this to happen. These adaptations must be seen to be in harmony with the Christian faith in South Africa and elsewhere.

\subsection{Superficial inculturation}

The absence of the fourth "self", as argued above, will continue to render the church powerless and incompetent in dealing with cultural issues confronting the church. The cosmetic cultural treatment, coupled with the cut and paste approach adopted by the church indirectly, makes the church less relevant than it should be. While the church purports to be against any form of ancestral worship, it actually finds itself engaged by default in cultural aspects that owe their legitimacy to the belief in the living-dead or ancestors. The church should be consistent in applying the biblical guidelines to all aspects of members' lives. However, the church should be very careful not to misrepresent culture and warn against acceptable cultural aspects.

\subsubsection{Significance of the ritual of circumcision}

The only Biblical text that can be used in dealing with circumcision is the one found in 1 Corinthians 9:18-23. This does not only address the issue of circumcision, it deals with all issues that are socio-cultural in nature.

We have argued that there was no appeal against this principle when Timothy was circumcised. His circumcision was expedient and not prudent. We also saw that Titus was not circumcised and again this principle was not applied. It would appear that the above principle was never used to contradict or modify the Jerusalem resolution on circumcision. It is apparent from the foregoing arguments that Xhosaspeaking Christians view the ritual of circumcision as something that has intrinsic value and meaning. It is what the ritual can effect in people that motivates them to observe it and not the principle found in 1 Corinthians 9:18-23. 


\subsubsection{Complex nature of the ritual of circumcision}

Due to the complex nature of circumcision, especially among Xhosaspeaking people, a complete abandonment of the ritual, in the foreseeable future, is not a possibility or an option for Xhosa-speaking Christians. Circumcision is firstly a family (including extended family) affair. It is the family that organises, monitors and validates the whole process of circumcision. It would be difficult for the child on his own to decide not to go for circumcision. Without visible support from the family, the child might be put in an awkward position and may be alienated by the family. While the decision to go for circumcision may lie with an individual member, the church should play the role of supporting its members by clarifying its position and indicating the options they have.

There could also be instances in which the parents are convinced that their child should not go for circumcision, and the child in question might not be convinced about this or may yield to pressure from his peers, and may participate in the ritual without parental consent, since this is not paramount on such occasions. Some parents may decide to circumcise the child in its infancy to avoid all these complications. These are the decisions that each family must wrestle with. The church as a family must be seen to be supporting its members and giving advice and suggesting options, regardless of the complexity of the problem.

\subsubsection{The involvement of the church}

As far as it is possible the church must not be involved in the ritual. It should remain a family ceremony. Currently, next to weddings and funerals, circumcision is the biggest event, even for church members. This forces the church to advance theological and Biblical justification for the ritual. The church is not usually involved in birthday celebrations, which families organise and friends and relatives attend. Circumcision could be dealt with in a similar fashion.

The church's theology regarding circumcision should not only be made clear to its members; it needs to find creative ways of sharing its views on circumcision. Any change in the way the ritual is observed should be clearly founded on a comprehensive theoretical foundation that is based on the Bible. 
The greatest challenge facing Xhosa-speaking Christians concerns how to de-emphasise the importance of the ritual of circumcision while practising it. Currently, Xhosa-speaking Christians not only observe the ritual but also attach the same meaning and significance to it as do the traditional Xhosa-speaking people. This has led to a situation in which boys from Christian families tend to regard the ritual of circumcision as being far more significant than a relationship with Christ.

The suggestion is therefore to find creative ways in emphasising other specific Christian aspects of growth into adulthood such as baptism (in churches where adult baptism is practised) or confirmation (in other churches).

\section{CONCLUSION}

The observation made here is that most Xhosa-speaking Christians still believe in the efficacy and the life-changing virtue of circumcision. The jury is still out on the impact that this compromise has for the Xhosaspeaking Adventist church. At a time when even the traditional Xhosa-speaking people are looking for a solution to the problems currently being experienced concerning this ritual, the church is preaching and defending, by default, the value and importance of this ritual.

The Christian church at large should give serious attention to the aspects of inculturation and contextualisation of the traditional belief systems in the church. The church should not compromise when the biblical truth is being displaced by unbiblical practices. However, clear guidelines are needed for replacing cultural aspects with something new. Continued study is needed for the church to be able to give sound advice on matters such as circumcision and other aspects regarding inculturation and contextualisation. The truth of the gospel in Jesus Christ should, however, not be compromised. 


\section{BIBLIOGRAPHY}

BEDIAKO, K.

1995. Christianity in Africa: the renewal of a non-Western religion. Edinburgh: Edinburgh University.

BROWN, R.E.

1997. An introduction to the New Testament. New York: Doubleday.

Bosch, D.J.

1991. Transforming mission. Paradigm shifts in theology of mission. New York: Orbis Books.

DOCUMENT Box 1.

Xhosa customs. National Heritage and Cultural Studies Centre, University of Fort Hare.

DRIVER, T.F.

1991. The magic of ritual: our need for liberating rites that transform our lives and our communities. New York: HarperCollins.

DunN, J.D.G.

1996. The Acts of the Apostles. Valley Forge, Pennsylvania: Trinity Press International. 1998. The theology of Paul the apostle. Edinburgh: T. \& T. Clark.

GONZALEZ, J.L.

2001. Acts: the Gospel of the Spirit. Maryknoll, NY: Orbis.

GITYWA, V.Z.

1976. Male initiation in the Ciskei: formal incorporation into Bantu society. Unpublished Doctoral Dissertation. Fort Hare University.

Hesselgrave, D.J.

1991. Communicating Christ cross-culturally: an introduction to missionary communication. Grand Rapids, Mi.: Zondervan.

HunTer, M.

1936. Reaction to conquest: effects of contact with Europeans on the Pondo of South Africa. London: Humphrey Milford.

KLINE, M.G.

1967. By oath consigned. Grand Rapids, Mi.:Eerdmans.

LA FonTAINe, J.S.

1985. Initiation: ritual drama and secret knowledge across the world. New York: Viking Penguin.

Magubane, P.

1998. Vanishing cultures of South Africa. Cape Town: Struik.

MBITI, J.S.

1969. African religions and philosophy. London: Heinemann. 


\section{Papu \& Verster Circumcision among Xhosa-speaking Christians}

MCCOMSKEY, T.E.

1985. The covenants of promise. A theology of the Old Testament covenants. Grand Rapids, Mi.:Baker.

MeintJies, G.

1998. Manhood at a price: socio-medical perspectives on Xhosa traditional circumcision. Rhodes University, Grahamstown: Institute of Social and Economic Research.

\section{NgXamngXa, A.N.H.}

1971. The function of circumcision among the Xhosa-speaking tribes in historical perspective. In: E.J. de Jager, (ed.), Man: anthropological essays presented to O.F. Raum. Cape Town: Struik.

OKURE, T. 1990. Inculturation of Christianity in Africa. Kenya: Amecea Gaba Publications.

PAUW, B.A.

1975. Christianity and Xhosa tradition: belief and ritual among Xhosa-speaking Christians. London: Oxford Univ. Press.

Polhill, B.J.

1992. Acts. Nashville Tennessee: Broadman Press. New American Commentary 26.

RIDDERBOS, N.H.

1979. The Epistle of Paul to the churches of Galatia. Grand Rapids, Mi.: Eerdmans. The New International Commentary on the New Testament.

ROBERTSON, O.P.

1993. Covenants. God's way with his people. USA: Great Commission Publication.

SOGA, H.J.

1931. The Ama-Xosa life and custom. South Africa: Lovedale.

SPENCER, S.F.

1997. Acts. Sheffield: Sheffield Academic Press.

SUNDAY TIMES

(London) 29 Dec. 1996:18.

VAN DER VLIET, V.

1974. Growing up in traditional society. In: W.D. Hammond-Tooke (ed.), The Bantu-speaking peoples of Southern Africa. London: Routledge \& Kegan Paul.

VAN DER WALT, B.J.

2003. Understanding and rebuilding Africa: from desperation today to expectation for tomorrow. Potchefstroom: The Institute for Christianity in Africa.

WALTON, J.H.

1994. Covenant: God's purpose, God's plan. Grand Rapids, Mi.: Zondervan.

Wenham, G.J.

1994. Genesis 16-50. Waco Texas: Word books. Word Biblical Commentary 2. 
Acta Theologica

YOUNG, F.W.

1965. Initiation ceremonies: a cross-cultural study of status dramatization. New York: Hobbs-Merrill.

Key concepts

Inculturation

Circumcision

Xhosa-speaking Christians

Bible and circumcision
Trefwoorde

Inkulturasie

Besnydenis

Xhosa-sprekende Christene

Die Bybel en besnydenis 